\title{
Pure-breeding with sexed semen and crossbreeding with semen of double-muscled sires to improve beef production from dairy herds: Factors affecting heifer and cow fertility and the sex ratio
}

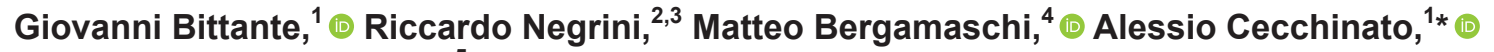 \\ and Hugo Toledo-Alvarado ${ }^{5}$ (C) \\ ${ }^{1}$ Department of Agronomy, Food, Natural Resources, Animals and Environment (DAFNAE), University of Padova (Padua), 35020 Legnaro (PD), \\ Italy \\ ${ }^{2}$ Department of Animal Science, Food and Nutrition (DIANA), Catholic University, 29122 Piacenza, Italy \\ ${ }^{3}$ Italian Association of Breeders (AIA), 00161 Rome, Italy \\ ${ }^{4}$ Department of Animal Science, North Carolina State University, Raleigh 27695 \\ ${ }^{5}$ Department of Genetics and Biostatistics, National Autonomous University of Mexico, Ciudad Universitaria, 04510, Mexico City, Mexico
}

\begin{abstract}
Using sexed semen to produce purebred replacement heifers makes it possible to mate a large proportion of dairy cows to double-muscled sires and to quantitatively and qualitatively improve beef production and increase the income from dairy herds. Net profit first depends on changes in the farm's overall fertility rate. The objective of this study was to analyze the conception rate in herds using a combination of conventional dairy semen (for pure- and crossbreeding), X-sorted dairy semen (to produce purebred replacement heifers), and conventional beef semen (for terminal crossbreeding). Data were obtained from 50,785 inseminations of 15,580 dairy cows (78\% Holstein-Friesian, 15\% Brown Swiss, 2\% Simmental, and 5\% crossbreds) from 106 dairy farms (average milk yield $35.1 \pm 9.4 \mathrm{~kg} / \mathrm{d}$, with $3.76 \pm 0.83 \%$ fat and $3.32 \pm 0.39 \%$ protein contents). To account for the main potential confounders, we used separate generalized linear mixed-effects models for cows and virgin heifers. The results showed that the odds ratio of conception improved (1.00 to 1.34) with an increase in the average milk yield of the herd but worsened (1.12 to 0.70) with an increase in the milk yield of individual cows within herd. The summer months showed a strong reduction in the odds ratio of conception in cows (0.56 in July and August) but not in virgin heifers. Multiparous cows had a lower odds ratio of conception (0.85) than primiparous cows (1.00). The order of insemination did not affect the fertility of the cows or heifers, whereas the odds ratio of conception improved with advancing lactation (1.00
\end{abstract}

Received November 19, 2019.

Accepted February 4, 2020.

*Corresponding author: Alessio.cecchinato@unipd.it to 2.12). The Simmental cows were more fertile than Holstein-Friesians (1.37 vs. 1.00), whereas the fertility of the heifers was not affected by breed. Taking all these possible confounders into account simultaneously, in pure-breeding the odds ratio of conception using sexed semen did not differ from that using conventional dairy semen in cows (0.90 vs. 1.00) or in virgin heifers $(0.95$ vs. 1.00). However, crossbreeding using conventional beef and dairy semen improved the odds ratio of conception (1.10 and 1.17, respectively) in cows (1.37 using beef semen) and heifers (1.25 using dairy semen). The proportion of newborn heifer calves was $\geq 90 \%$ using sexed dairy semen. The combined use of sexed semen, especially on heifers, to produce purebred replacement females and beef semen to produce terminal crossbred calves was shown to have the potential to increase overall herd fertility, which could be further improved using sexed dairy semen to produce dairy crossbreds instead of purebred replacement heifers.

Key words: X-sorted semen, beef cross, dairy breed, replacement heifer, heat stress on fertility

\section{INTRODUCTION}

In the past, one way to maintain a high level of meat production on dairy farms was to crossbreed dairy cows no longer needed for producing purebred replacement heifers with beef bulls to produce crossbred slaughter animals (Dal Zotto et al., 2009). Progressive specialization and intensification of dairy farms and selection of animals has led to considerable improvement in milk production but a correlated decrease in the fertility and longevity of the cows (Lucy, 2001; VanRaden, 2004). This increased the replacement rate and caused the near disappearance of terminal crossing of dairy cows with beef bulls. Meat production from dairy herds became marginal, limited almost entirely to cull cows and 
newborn male dairy calves, the latter sold mainly for veal production (European Commission, 2011). The genetic improvement of dairy breeds for milk production worsened the characteristics of the meat and lowered the price of culled cows and newborn calves (Mc Hugh et al., 2010).

In recent years, the difficulty of obtaining sufficient heifers to replace culled cows motivated the use of $\mathrm{X}$-sorted semen to increase the proportion of females among newborn calves (Hohenboken, 1999). However, widespread use of sexed semen was hindered by its higher price and evidence of lower fertility (Cerchiaro et al., 2007) compared with conventional semen. More recently, these drawbacks have become less of a problem (Lenz et al., 2017; Vishwanath and Moreno, 2018), and the use of sexed semen is now increasing (Heuer et al., 2017) and is worthwhile not only for producing replacement females but also as a way of boosting farm income by increasing the number of dairy cows for terminal crossbreeding with beef sires (Ettema et al., 2017).

In their review of the applications and benefits of sexed semen in dairy and beef herds, Holden and Butler (2018) stated that the use of sexed semen can increase herd genetic gain compared with use of nonsorted semen and that a sustainable breeding strategy could be to combine the use of sexed semen to generate replacements with the use of beef semen on all of the females that are not suitable for generating replacements. This would increase the genetic gain in dairy herds, increase the value of beef output from dairy herds, and reduce greenhouse gas emissions from beef production. The same authors concluded, however, that even a small reduction in fertility as a result of using sexed semen compared with conventional semen can negate much of the economic benefit.

Several studies have compared the fertility of sexed and conventional semen in pure-breeding operations, and fewer studies have examined the fertility of conventional semen in crossbreeding. The authors are unaware of any studies on the combined use of both types of semen in the same herd.

A large project was carried out in the Veneto region (northeastern Italy) to estimate the effect of several factors on cow fertility and to evaluate in field conditions the suitability of combining the use of sexed dairy semen to produce purebred replacement heifers with the use of conventional beef semen to produce terminal beef $\times$ dairy crossbred calves. A particular focus was put on the effects on the fertility of the dairy herd and on the value, performance, and meat quality of the resulting crossbred calves.

The main objective of this study was to compare the conception rate and sex ratio of newborn calves from inseminations with sexed semen to produce purebred calves from bulls of dairy breeds and conventional semen to produce crossbred calves from bulls of beef breeds. We took into account possible confounding factors affecting the estimates obtained in the field and included the simultaneous effect of several sources of variation, particularly at the herd productivity level, the cow productivity level within herd, and the cow's breed, parity, order of insemination, lactation stage, and calendar month of insemination.

\section{MATERIALS AND METHODS}

\section{Dairy Farms and Cows}

The present study is part of the meetBULL project (funded by the Veneto regional government, Italy) aimed at increasing the quantity and quality of meat production from dairy herds through the combined use of sexed semen from dairy bulls to obtain purebred replacement heifers and conventional semen from beef bulls to obtain crossbred calves destined for veal and beef production. An indirect objective of the project is also to link the region's specialized beef fattening centers (using mainly imported beef stock calves) to the dairy farms with regard to their supply of calves.

A total of 125 dairy farms in the Veneto region (northeastern Italy) were enrolled in the project. All of the farms were participating in the milk recording system of the Veneto Breeders Association (Associazione Regionale Allevatori del Veneto, Vicenza, Italy), and the purebred cows were registered in the herd books of their corresponding dairy breed. Some of the herds were discarded after editing the data for quality control, leaving 106 herds for the analyses. The majority of the herds were kept on modern intensive dairy farms using TMR based on corn silage, some dry forages, and concentrates. On average, the dairy farms reared 48 \pm 45 replacement heifers and managed $98 \pm 91$ dairy cows (78\% Holstein-Friesian, 15\% Brown Swiss, 2\% Simmental, and $5 \%$ crossbreds). The average milk yield was $35.1 \pm 9.4 \mathrm{~kg} / \mathrm{d}$, with $3.76 \pm 0.83 \%$ fat and 3.32 $\pm 0.39 \%$ protein contents. Descriptive statistics of the daily milk yield and composition according to breed of cow are given in Table 1. The milk is primarily destined for the production of Protected Designation of Origin cheeses (Stocco et al., 2019) in accordance with regulations approved by the European Union (e.g., Grana Padano, Asiago, Montasio, Monte Veronese, Piave, Casatella Trevigiana).

\section{Inseminations}

Almost all the cows and heifers were artificially inseminated by the farmer. Because an objective of the 
project is to operate in the real conditions of commercial dairy farms, the type, breed, and origin of semen was not restricted but rather was decided by the farmer. The technical advice given to farmers was to use sexed semen on part of the herd, especially the heifers, for purebred replacement and conventional dairy semen on the best cows. It was suggested that they use beef semen, mainly from double-muscled breeds, on the other cows not needed for replacement.

Insemination and calving data were obtained from the Veneto Breeders Association. In total, 50,785 inseminations performed over 5 yr (2014-2018), including 39,685 on dairy cows and 11,100 on virgin heifers, were monitored. We retained only those inseminations for which the herd name, individual cow or heifer ID, date of insemination, type of semen (sexed or conventional), breed of bull, bull ID, and pregnancy diagnosis were recorded. In addition, the farm name, cow ID, date, and the calf's sex for each calving were recorded.

\section{Statistical Analysis}

Data Editing. All records with incomplete information were excluded from the statistical analysis. Sick or injured heifers, cows, and calves were also discarded. Gestation length was required to be greater than $225 \mathrm{~d}$ and less than $315 \mathrm{~d}$. The conception rate was coded as a binary variable, where 1 indicated a cow that became pregnant in a given insemination, confirmed by the subsequent calving or by positive confirmation from a veterinarian, and 0 indicated no resulting pregnancy. Two subsequent inseminations were required to be carried out within $155 \mathrm{~d}$; otherwise, the reproductive event was discarded (1\% of events). The data set was divided into cows and heifers, and different effects were included in each model.

All records with missing or abnormal values were discarded from the milk production and composition data set. Lactation period was divided into 10 categories of DIM, each of $30 \mathrm{~d}$ except the last, an open category of $>270$ DIM. Breeds with few data (Red Danish, Montbéliarde, and Jersey) were excluded from the analysis.

Herd and Cow Classification According to Milk Yield. To establish the production levels of the herds (PL-H) and the cows within herd (PL-C), 2 mixed models were fitted in the $\mathrm{R}$ environment ( $\mathrm{R}$ Core Team, 2016). The mixed model for PL-H was

$$
y_{i j k}=\mu+P D_{i}+Y S_{j}+\operatorname{Herd}_{k}+\varepsilon_{i j k}
$$

and for PL-C it was

$$
y_{i j l m}=\mu+P D_{i}+Y S_{j}+H L_{l}+\text { Cow }_{m}+\varepsilon_{i j l m},
$$

where $y_{i j k}$ is the milk production on the test day; $\mu$ is the intercept; $P D_{i}$ is the fixed systematic effect of parity-DIM $i$ [parities were grouped into 5 classes $(1,2,3$, 4 , and $\geq 5$ ), and DIM were grouped into 10 classes]; $Y S_{j}$ is the systematic effect of year-season $j$ (year $=2014$ to 2018; season $=$ class 1: April to September, class 2: October to March); $\operatorname{Herd}_{k}$ is the random effect of herd $k(k=106$ herds $)$; and $\varepsilon_{i j k} \sim N I I D\left(0, \sigma_{e}^{2}\right)$ is the random residual for the PL-H model, where $\sigma_{e}^{2}$ is the variance of the error; $y_{i j l m}$ is the milk production on the test day; $H L_{l}$ is the random herds' solutions from the PL-H mixed model classified into 5 milk productivity levels $(l$ $=1$ to 5); Cow $_{m}$ is the random effect of cow $m(m=$ 14,744 animals); and $\varepsilon_{i j l m} \sim \operatorname{NIID}\left(0, \sigma_{e}^{2}\right)$ is the random residual for the PL-C model, where $\sigma_{e}^{2}$ is the variance of the error. The random solutions of the cow's effect were then used to classify them into 5 milk productivity levels (PL-C 1 to 5 ). The 5 PL-H classes and the 5 PL-C classes were defined according to the BLUP values of the herds or cows, respectively (level 1: BLUP $<-1.5$ SD; level 2: BLUP $>-1.5$ and $<-0.5$ SD; level 3 : BLUP $>-0.5$ and $<0.5 \mathrm{SD}$; level 4 : BLUP $>0.5$ and $<1.5$ SD; level 5: BLUP $>1.5$ SD).

Analysis of Calving Rate. To study the conception rate, the generalized linear mixed-effects models were fitted with a binomial link logit: $\eta_{i}=\ln \left[\mu_{i} /(1-\right.$ $\left.\mu_{i}\right)$ ], where $\eta_{i}$ is the response probability of becoming pregnant for conception rate. The model had the form

$$
y=\eta+e=\alpha+\mathbf{X} \boldsymbol{\beta}+\mathbf{Z u}+e,
$$

where $\alpha$ is the intercept of the parameter; $\mathbf{X}$ is the design matrix for the fixed effects; $\boldsymbol{\beta}=\left(\beta_{1}, \ldots, \beta_{i}\right)$ are vectors of the effects associated with the columns of

Table 1. Descriptive statistics (average $\pm \mathrm{SD}$ ) of milk yield and composition of inseminated dairy cows according breed

\begin{tabular}{lcccccc}
\hline Breed & Test dates (no.) & Herds (no.) & Milk yield (kg/d) & Fat (\%) & Protein (\%) \\
\hline Holstein-Friesian & 46,148 & 95 & $36.1 \pm 9.6$ & $3.71 \pm 0.82$ & $3.26 \pm 0.37$ & $4.27 \pm 1.14$ \\
Brown Swiss & 8,638 & 32 & $30.9 \pm 7.3$ & $4.04 \pm 0.82$ & $3.61 \pm 0.38$ & $3.98 \pm 1.16$ \\
Simmental & 1,373 & 18 & $30.0 \pm 8.3$ & $3.82 \pm 0.86$ & $3.39 \pm 0.37$ & $4.08 \pm 1.21$ \\
Crossbred & 2,914 & 64 & $33.0 \pm 8.8$ & $3.75 \pm 0.81$ & $3.38 \pm 0.36$ & $4.12 \pm 1.16$ \\
\hline
\end{tabular}


$\mathbf{X} ; \mathbf{Z}$ is design matrix for the random effects; and $\mathbf{u}=$ $\left(u_{1}, \ldots, u_{i}\right)$ are vectors of the random effects. Equivalently, the residual variability can be modeled as $y \mid u \sim$ $[h(n), R]$, which specifies the conditional distribution of $y$ given that $u$ has the mean $h(n)$ and the variance $R$.

The model for the cows included the fixed effects of month (January to December); the order of lactation (first, second, third or greater); the effect of the order of insemination (first, second, third, fourth or greater); the effect of breeding strategy (pure-breeding with conventional semen, pure-breeding with sexed semen, crossbreeding with conventional semen of beef bulls, crossbreeding with conventional semen of dairy bulls) according to the breed of the sire used for the insemination (the sire beef breeds were Aberdeen Angus, Belgian Blue, Charolaise, INRA95, Limousine, Piedmontese; the sire dairy breeds were Brown Swiss, Holstein-Friesian, Jersey, Norwegian Red, Rendena, Simmental, Sweden Red); the effect of the cow' breed (Holstein-Friesian, crossbred, Brown Swiss, Simmental); the effect of DIM (8 categories); the effect of the PL-H (5 milk productivity levels); the effect of the PL-C within herd (5 milk productivity levels); and, finally, the random effect of herd-breed nested in the breed of the cow. The model for heifers included the same effects as the model for cows except for the effects of the order of lactation, DIM, the PL-H, and the PL-C. All data editing and statistical analyses were carried out in the $\mathrm{R}$ environment (R Core Team, 2016).

\section{RESULTS AND DISCUSSION}

We attained our main objective of evaluating the effect on herd fertility of the combined use of sexed dairy semen to produce replacement heifers and conventional beef semen to produce crossbred calves for meat production by including in the statistical model the effects of all the major possible confounding factors. We briefly describe and discuss the effects of these factors before analyzing the results of our evaluation.

\section{Effects of Herd and Cow Productivity on the Conception Rate of the Cows}

The fertility of dairy cows is strongly affected by the level of milk production (Lucy, 2001; Walsh et al., 2011; López-Gatius, 2012). In the scientific literature, it is not always possible to clearly disentangle the effects on fertility of all the different factors affecting milk yield, particularly herd productivity, the individual cow's potential (including its genetics), and its parity and stage of lactation. Bello et al. (2012) outlined the biases and misinterpretations deriving from inadequate modeling of fertility data when the objective of the research is the relationship with milk productivity. All of the above-mentioned factors were included in our statistical model and then evaluated independently of each other.

Morton (2006) clearly stated that inferences on the associations between milk production and reproductive performance at the individual (i.e., cow) level may be confounded with inferences on the associations at the aggregate population (i.e., herd) level, and so these 2 levels should be clearly identified. Our results showed that, after correcting the data for all the other confounding factors, cows reared on farms characterized by a higher mean level of milk production had on average a better conception rate than cows reared on farms with lower productivity (Figure 1). In a similar study carried out in a different environment (mountainous areas with lower milk production levels), we found a tendency for a curvilinear response, with a reduction of average conception rate increasing the mean herd milk yield up to 20 to $25 \mathrm{~kg} / \mathrm{d}$ and an improvement of conception rate increasing further mean herd milk yield level to 30 to $35 \mathrm{~kg} / \mathrm{d}$ (Toledo-Alvarado et al., 2017). These tendencies were more pronounced in dual-purpose breeds, such as Simmental, and less evident in specialized dairy breeds, such as Holstein-Friesian and Brown Swiss. It is worth noting that there was a clear reduction in the average days open with increasing mean herd milk yield for all breeds except Holstein-Friesian. As pointed out by LeBlanc (2010), "it is important to separate the biology of reproductive function from the effects of economically-based management decisions about culling and continuation of breeding." So, it is clear that favorable environmental and management factors (e.g., farmers' skills, farm buildings and facilities, feeding regimens, milking practices, disease prevention) that promote higher mean herd milk production levels also have a positive effect on cow reproduction efficiency.

With regard to individual cow productivity, the odds ratios plotted in Figure 1 show the opposite situation: cows (in the same herds, of the same breed, and with the same parity, lactation stage, and order of insemination) with greater milk production exhibited a lower conception rate than cows with lower milk production. This pattern fully confirms the results obtained in the previous study on the effect of milk yield on fertility at the levels of herd and individual cow within herd (Toledo-Alvarado et al., 2017). These results are expected given the physiological (Lucy, 2003) and genetic (Castillo-Juarez et al., 2000; Pryce et al., 2004; Tiezzi et al., 2011) antagonism between production and reproduction, mediated by the energy balance and BCS of lactating dairy cows (Butler, 2003; Tiezzi et al., 2013). 
Effects of Season of Insemination on the Conception Rates of Cows and Heifers

The effect of calendar month of insemination strongly affected the conception rate of the dairy cows but was not significant for heifers (Figure 2). The odds ratio of the conception rate of lactating cows almost halved in July and August, the warmest months of the year, compared with January and February, the coldest ones. Fertility depression during summer is clearly connected

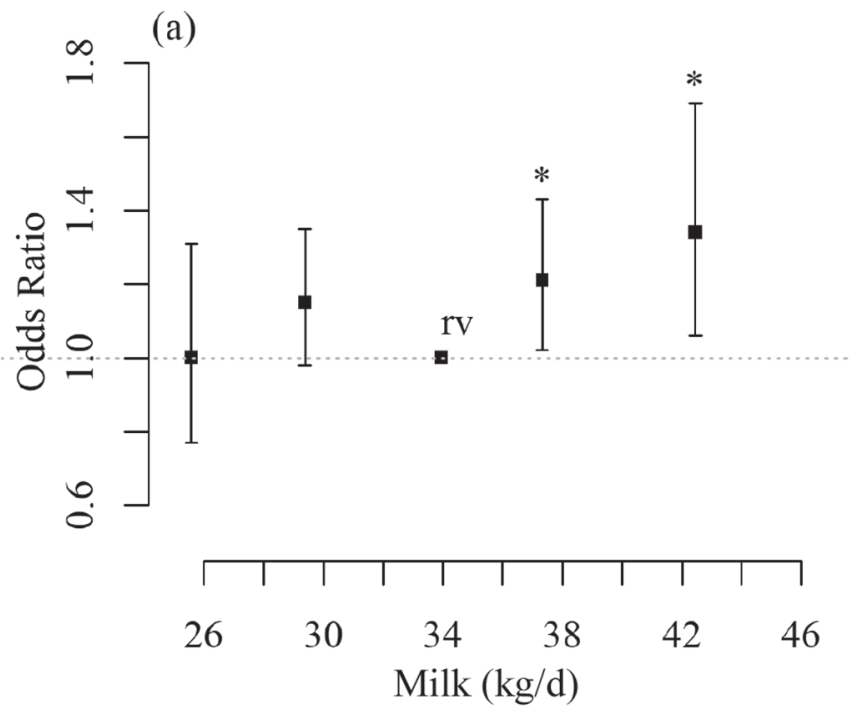

(b)

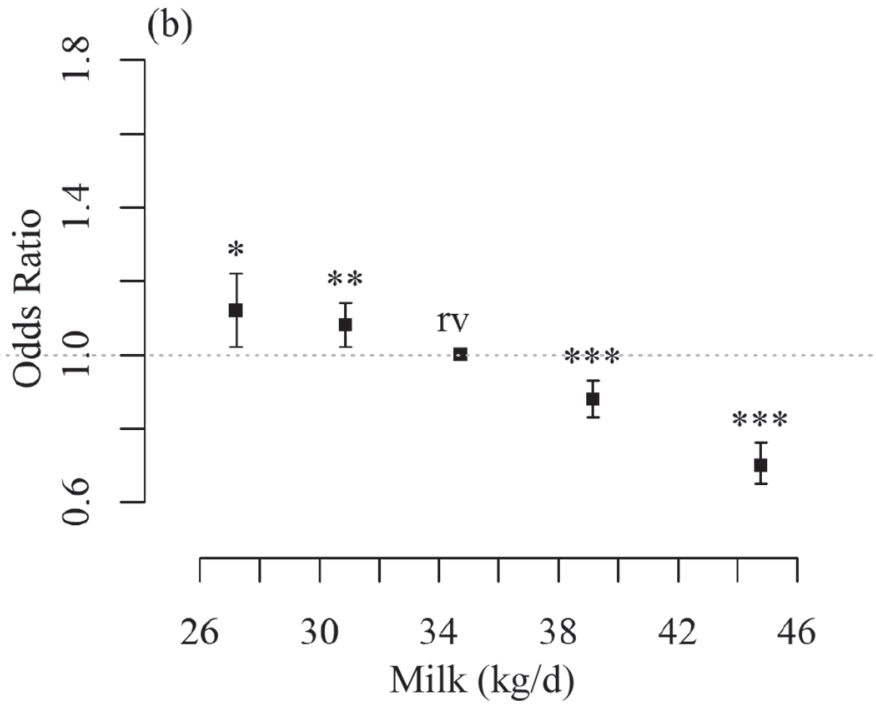

Figure 1. Odds ratio estimates and their confidence intervals for the conception rate of cows according to the milk production at (a) herd level (5 classes according to the herd average of milk yield) or (b) cow-within-herd level (5 classes of individual cow milk yield within herd). $\mathrm{rv}=$ reference value. Asterisks indicate the significance of the difference with the reference value $\left({ }^{*} P<0.05\right.$; ${ }^{* *} P<0.01$; ${ }^{* * *} P<$ $0.001)$. with the level of heat stress, which first depends on the climate in the area and on the latitude and altitude of the dairy farm (Dash et al., 2016; Kim and Jeong, 2019; Scanavez et al., 2019). According to the KöppenGeiger classification (Beck et al., 2018), the climate in the Veneto plains is temperate with no dry season and hot summers (Köppen climate classification: Cfa). It is worth noting that the pattern of odds ratios of conception rates over the different calendar months resembles the inverse of the curve of average temperature more closely than that of daily radiation.

(a)

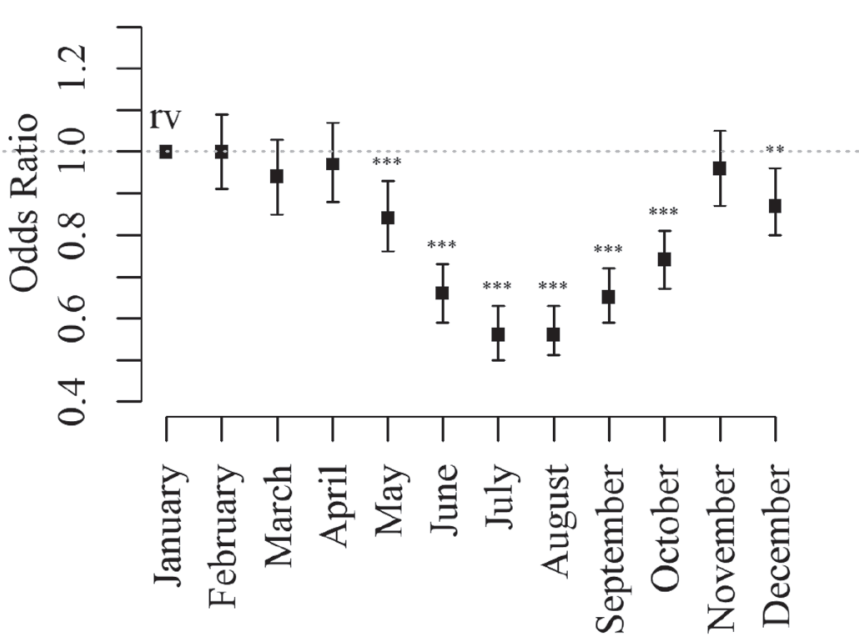

Month

(b)

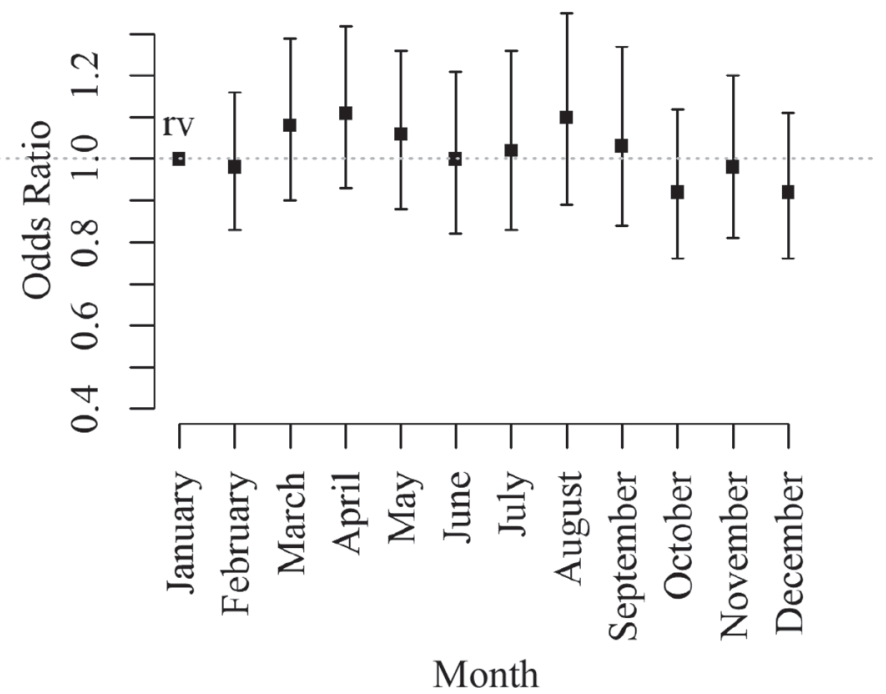

Figure 2. Odds ratio estimates and their confidence intervals for the conception rate of (a) cows and (b) heifers across months of the year. $\mathrm{rv}=$ reference value. ${ }^{* *} P<0.01 ;{ }^{* * *} P<0.001$. 


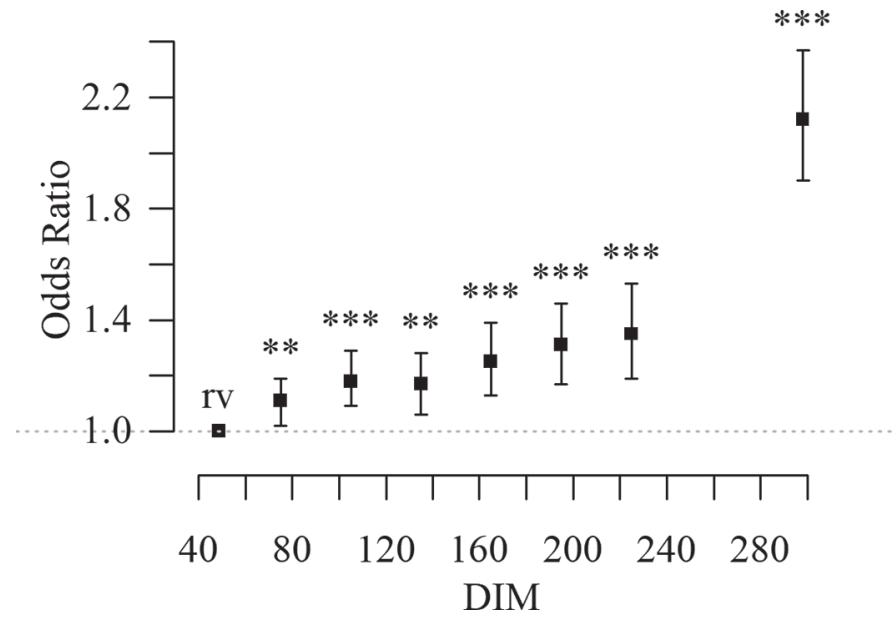

Figure 3. Odds ratio estimates and their confidence intervals for the conception rate of cows across the DIM classes. $\mathrm{rv}=$ reference value. ${ }^{* *} P<0.01 ;{ }^{* * *} P<0.001$.

As reviewed by De Rensis et al. (2017), a reduction in feed intake occurs during the warm season, which may compromise the cow's energy balance or induce an imbalance in the activity of the hypothalamo-hypophyseal-ovarian axis. These factors lower the lactating cow's reproductive performance and compromise the quality of the oocytes, embryos, and corpora lutea. It is also evident that heat stress particularly affects lactating cows because of their metabolic burden due to the high nutrient requirement for milk synthesis. This is not the case for replacement heifers (Figure 2), who are known to have a greater tolerance to high temperatures and humidity levels than cows (Healy et al., 2013; Hagiya et al., 2017).

\section{Effects of Parity, Lactation Stage, and Order of Insemination on the Conception Rate of Cows and Heifers}

Not having the contemporary metabolic burden of milk production, as expected, virgin heifers were much more fertile than lactating dairy cows and are characterized by different factors of variation and variance structures (Tiezzi et al., 2012). Their data were therefore analyzed separately. Among the lactating cows, the odds ratio of conception was lower for multiparous than for primiparous cows (Table 2); this was often the case with the high-producing Holstein-Friesian cows, but not in less intensive dairy systems (Toledo-Alvarado et al., 2017).

Within lactation, the effects of order of insemination and DIM are clearly intermingled, and there is a risk of confusing them because successive estruses and then inseminations in the same cow appear with advancing lactation. If included one at a time in the statistical model, a clear increase occurs in the conception rate with increasing order of insemination or of lactation stage (Butler et al., 2014). We included these 2 factors together in the analytical model, and the result was a considerable improvement (Figure 3) in the odds ratio of conception with increasing DIM, independently of the order of insemination, and a nonsignificant effect of this factor (Table 2) when lactation stage was taken

Table 2. Effects $(\beta \pm \mathrm{SE})$ and odds ratio $(\mathrm{OR})$ with confidence interval of different factors on conception rate of dairy cows ${ }^{1}$

\begin{tabular}{|c|c|c|c|c|}
\hline Factor & No. & $\beta \pm \mathrm{SE}$ & OR & $95 \% \mathrm{CI}$ \\
\hline \multicolumn{5}{|l|}{ Parity of cows at insemination } \\
\hline First & 13,621 & Referent & 1.00 & - \\
\hline Second or greater & 26,064 & $-0.16^{* * *} \pm 0.02$ & 0.85 & $0.81-0.89$ \\
\hline \multicolumn{5}{|l|}{ Insemination order within parity } \\
\hline First & 16,962 & Referent & 1.00 & \\
\hline Second & 9,675 & $0.04 \pm 0.03$ & 1.04 & $0.98-1.11$ \\
\hline Third & 5,540 & $-0.01 \pm 0.04$ & 0.99 & $0.92-1.07$ \\
\hline Fourth or greater & 7,508 & $-0.03 \pm 0.04$ & 0.97 & $0.89-1.06$ \\
\hline \multicolumn{5}{|l|}{ Breed } \\
\hline Holstein-Friesian & 30,902 & Referent & 1.00 & - \\
\hline Brown Swiss & 6,028 & $-0.06 \pm 0.09$ & 0.94 & $0.78-1.13$ \\
\hline Simmental & 881 & $0.31^{*} \pm 0.14$ & 1.37 & $1.05-1.78$ \\
\hline Crossbred & 1,874 & $0.06 \pm 0.09$ & 1.06 & $0.89-1.26$ \\
\hline \multicolumn{5}{|l|}{ Type of insemination } \\
\hline Pure-breeding, conventional & 23,277 & Referent & 1.00 & - \\
\hline Pure-breeding, sexed & 832 & $-0.10 \pm 0.08$ & 0.90 & $0.77-1.06$ \\
\hline Crossbreeding, beef bulls & 13,638 & $0.09^{* * *} \pm 0.03$ & 1.10 & $1.04-1.16$ \\
\hline Crossbreeding, dairy bulls & 1,938 & $0.16^{* *} \pm 0.06$ & 1.17 & $1.04-1.32$ \\
\hline
\end{tabular}

${ }^{*} P<0.05 ;{ }^{* *} P<0.01$; ${ }^{* * *} P<0.001$.

${ }^{1} \beta$ is the estimated effect. 
into account (different orders of insemination at the same DIM).

The favorable effect of advancing DIM on the fertility of dairy cows is related, at the beginning, to the evolution of the reproductive apparatus after calving in particular (Lucy, 2019), whereas later it is related to an improvement in energy balance (Lucy, 2003; Rodney et al., 2018). The odds ratio of conception of cows in the last class of DIM is very high because it also includes cows with a very low or null milk yield and with a metabolic condition more similar to that of virgin heifers than lactating cows.

In some studies (Hutchinson et al., 2013), sexed semen was used only at the first inseminations, and conventional dairy or beef semen was used on subsequent inseminations. The implicit assumption is that fertility decreases in subsequent services. This was not the case in the present study, provided that the cows being inseminated are healthy. To optimize the use of expensive sexed semen, it would seem advisable to avoid using it in cows in early lactation (negative energy balance) and concentrate instead on using it in heifers. In the case of virgin heifers, neither of these effects (of previous calving and lactation energy balance) is relevant, which explains their higher fertility and the fact that the order of insemination does not affect the odds ratio of conception (Table 3).

\section{Effects of Breed on the Conception Rates of Cows and Heifers}

The cow's breed also has some effect on its fertility. In particular, the Simmental cows, but not the Brown Swiss and crossbred cows, had a higher odds ratio of conception than the Holstein-Friesians (the reference breed; Table 2). The superiority of the dual-purpose breed over the specialized dairy breeds cannot be ascribed simply to its energy balance. Although it is true that Simmental cows were producing $11 \%$ less fat plus protein than the Holsteins (2.23 vs. $2.52 \mathrm{~kg} / \mathrm{d}$, respectively; Table 1), the Brown Swiss and crossbred cows were also producing less fat plus protein $(-6 \%$ and $-3 \%$, respectively) than the Holsteins. In a large survey on the effects of herd and individual cow productivity on the fertility of lactating cows of 4 different breeds (Toledo-Alvarado et al., 2017), we found that the 2 dual-purpose breeds (Simmental and Alpine Grey) were more fertile than the specialized dairy breeds (HolsteinFriesian and Brown Swiss), even within the same herd or with the same individual cow milk energy output. This could in large part be attributed to different ratios between milk yield and body energy resources (fat and, in part, protein). As indirect confirmation, it is worth noting that in the case of virgin heifers, where milk synthesis does not occur, there were no significant differences among the different breeds (Table 3 ).

\section{Effects of the Use of Sexed Semen on the Conception Rate of Cows and Heifers and the Sex Ratios of Newborn Calves}

After taking into account the simultaneous effects of herd and individual cow productivity, parity, order of insemination, lactation stage, and breed of cow, it was noted that the use of sexed semen for pure-breeding did not affect the odds ratio of conception of either dairy cows (Table 2) or virgin heifers (Table 3), even though it was numerically slightly lower than with

Table 3. Effects $(\beta \pm \mathrm{SE})$ and odds ratio $(\mathrm{OR})$ with confidence interval of different factors on conception rate of heifers ${ }^{1}$

\begin{tabular}{lrrrc}
\hline Factor & No. & $\beta \pm \mathrm{SE}$ & OR & $95 \%$ CI \\
\hline Insemination order & & & & \\
$\quad$ First & 6,714 & Referent & 1.00 & - \\
Second & 2,535 & $0.05 \pm 0.05$ & 1.05 & $0.95-1.15$ \\
Third & 1,010 & $0.11 \pm 0.07$ & 1.12 & $0.97-1.29$ \\
$\quad$ Fourth or greater & 841 & $-0.06 \pm 0.08$ & 0.94 & $0.80-1.10$ \\
Breed & & & & \\
$\quad$ Holstein-Friesian & 8,609 & Referent & 1.00 & - \\
Brown Swiss & 1,740 & $-0.24 \pm 0.13$ & 0.78 & $0.60-1.02$ \\
Simmental & 125 & $0.08 \pm 0.29$ & 1.08 & $0.61-1.91$ \\
Crossbred & 626 & $-0.17 \pm 0.20$ & 0.84 & $0.57-1.24$ \\
Type of insemination & & & & \\
$\quad$ Pure-breeding, conventional & 7,656 & Referent & 1.00 & - \\
Pure-breeding, sexed & 2,233 & $-0.05 \pm 0.06$ & 0.95 & $0.85-1.07$ \\
Crossbreeding, beef bulls & 496 & $0.32 * * \pm 0.11$ & 1.37 & $1.10-1.70$ \\
Crossbreeding, dairy bulls & 715 & $0.22 \pm 0.16$ & 1.25 & $0.91-1.71$ \\
\hline
\end{tabular}

$* * P<0.01$.

${ }^{1} \beta$ is the estimated effect. 


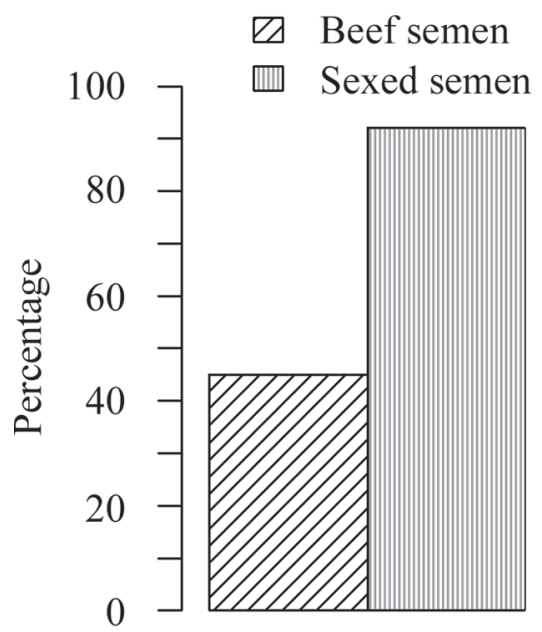

Cows

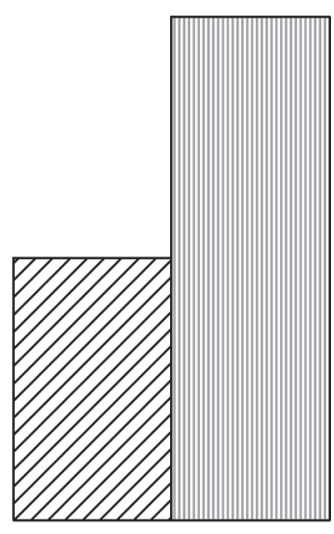

Heifers
Figure 4. Percentage of heifer calves born from dairy cows and heifers inseminated with sexed semen of their breed or with conventional beef semen.

the use of conventional semen. It is worth noting that until a decade ago the conception rate with sexed semen was 70 to $80 \%$ of that with conventional semen in indoor systems (Seidel, 2014; Kurykin et al., 2016) and in pasture-based systems (Butler et al., 2014). This lower reproductive efficiency could be due to lower semen fertility (Hayakawa, 2012) but perhaps also to the fetuses and calves obtained from sexed semen being less vigorous (Tubman et al., 2004; Djedović et al., 2016). Nowadays, improvements in sex sorting technology are reducing the fertility differential between sexed and conventional semen (Heuer et al., 2017; Lenz et al., 2017; Vishwanath and Moreno, 2018), which may explain the nonsignificant and only slight numerical effect of sexed semen on conception rate found in this study. The proportion of heifer calves obtained with X-sorted semen was more than $90 \%$ of all calves born compared with slightly less than $50 \%$ with conventional beef semen (Figure 4), confirming the results obtained in several previous studies (Healy et al., 2013; Seidel, 2014).

\section{Effects of the Use of Semen of Different Beef and Dairy Breeds on the Conception Rate of Cows and Heifers}

Crossbreeding with conventional semen of beef or dairy bulls increased the odds ratio of conception of the dairy cows (Table 2) and the virgin heifers (Table 3 ). In addition to the variations due to different breed combinations, which were not studied here because of the unequal distribution, the higher conception rate in both beef and dairy crossbreeding may be attributed mainly to the favorable effect of the crossbred embryo's heterosis on its survival.

If sexed semen is advantageous to the welfare of heifers and cows at calving by reducing the incidence of dystocia due to bull-calf births, where beef crossbreeding is concerned the situation is less clear because breed composition and sex ratio have opposite effects. Beef crossbreeding is expected to increase the incidence of dystocia, whereas replacing (purebred dairy) bull calves with (crossbred) bull and heifer calves is expected to reduce it. The final outcome will depend on the reproduction strategy adopted and the beef breeds and individual sires used.

The preferred beef breeds for beef $\times$ dairy crossbreeding in continental Europe are the double-muscled breeds (Dal Zotto et al., 2009; Mc Hugh et al., 2010). The Belgian Blue (Coopman et al., 2007) and Piedmontese (Albera et al., 2001; Kizilkaya et al., 2003) breeds are actively selected to improve their direct genetic effects on calving difficulties. Where the 2 breeds are very different is in their maternal genetic effects on calving ease, selected for in the Piedmontese but not in the Belgian Blue (Kizilkaya et al., 2003; Kolkman et al., 2007), although this trait does not concern firstgeneration terminal crossbreeding on dairy cows. Omission of maternal ease of calving in the selection index of the Belgian Blue has led to a rapid improvement in their beef traits and reduced sexual dimorphism (Bittante et al., 2018). This may explain the greater preference on the part of the farmers involved in this project for Belgian Blue semen (Bittante et al., 2020) over other double-muscled breeds (Piedmontese and INRA 95) and conventional beef breeds (Limousin and Simmental).

The use of purebred sexed semen on heifers and conventional double-muscled beef semen from breeds and sires selected for lower direct effects on calving difficulties on most cows may therefore be a valid compromise. The overall effect on the fertility of the entire herd could even be beneficial because the positive significant effect of using conventional beef semen seems to be greater than the possible (nonsignificant) effect of using sexed semen on heifers.

Last, the production of beef from specialized beef systems, also in northeastern Italy (Berton et al., 2017, 2018), is particularly affecting in terms of ecological footprint because the rearing of the suckler cows is allocated only to the production of the calf. Recent research (Holden and Butler, 2018) has suggested that improving the production of beef from dairy herds could be an effective way of reducing the ecological footprint 
of beef production (e.g., greenhouse gases, leaking nitrogen, land use, water use) because the maintenance of the cows is mainly allocated to the production of milk.

\section{Combined Use of Sexed Semen and Beef Semen to Increase the Profitability of Dairy Farms}

From an economic point of view, the use of sexed semen in dairy pure-breeding may result in a different expected net present value due to many factors. The most important are, of course, the cost of sexed semen, the fertility of the herd, and the reduction in fertility resulting from the use of sexed semen (Hutchinson et al., 2013; McCullock et al., 2013; Butler et al., 2014; Cottle et al., 2018). It worth noting that the first (semen cost) and third (lower fertility) factors are now of less importance because of improvements in sex-sorting technologies (Lenz et al., 2016; Heuer et al., 2017; Vishwanath and Moreno, 2018). This means that the expected net present value of sexed semen is increasing, especially when used on virgin heifers (BarrientosBlanco et al., 2018), and is independent of whether beef semen is used for crossbreeding with cows exceeding the need for replacement heifers. Moreover, the increasing financial advantage of using sexed, sorted semen is also related to the genetic improvement of the herd resulting from the use of sires of high net merit on the heifers and best cows (Ettema et al., 2017; Cottle et al., 2018).

The profitability of combining the use of sexed semen for pure-breeding and conventional beef semen for crossbreeding depends on improvements to the conception rate arising from the use of beef semen, but principally in the beef $x$ dairy bull and heifer calves having a greater value than the purebred dairy bull calves. In the prevailing conditions in Denmark, beef crossbred calves do not have a very high value, so the combined use of sexed dairy and conventional beef semen is not very profitable (Ettema et al., 2017); this is also the case in Ireland (Mc Hugh et al., 2010). In the conditions that prevail in countries with beef markets that favor lean, muscular carcasses, the higher value of crossbred calves, especially from double-muscled sires, is a much more important factor (Dal Zotto et al., 2009). In this project (Bittante et al., 2020), the beef crossbred bull and heifer calves were sold by dairy farmers to intensive veal and beef fatteners at an average of $€ 318 /$ calf at 5 wk of age (63 kg of live weight) against a price of $€ 80$ to $€ 100 /$ calf for dairy bull calves of the same age (ISMEA, 2019). The average price of Belgian Blue $\times$ HolsteinFriesian calves was $€ 363 /$ calf, an increase equivalent to the price of about $800 \mathrm{~L}$ of milk over the price of a purebred dairy bull calf.
Aside from the opportunities offered by the use of sexed semen to produce purebred replacement heifers, it is worth noting that this technique could also be used in rotational dairy crossbreeding systems. Compared with Holstein-Friesian pure-breeding, some of these reproductive schemes are known to offer the potential of maintaining almost the same daily yield of milk fat and protein (Malchiodi et al., 2014b; Saha et al., 2017, 2018) and improving the fertility (Buckley et al., 2014; Malchiodi et al., 2014a), fitness, and survival (Clasen et al., 2017; Hazel et al., 2017) of dairy cows, thereby reducing the replacement rate and improving the feed efficiency (Shonka-Martin et al., 2019) and economic efficiency (Heins et al., 2012) of the cows and the profitability of the dairy farm (Dezetter et al., 2017). Clearly, sexed semen of 2 or 3 different dairy breeds could be used on crossbred heifers (and cows) in rotational dairy crossbreeding systems, and this scenario increases the net present value of the dairy herd compared with Holstein pure-breeding (Barrientos-Blanco et al., 2018). This technique could, of course, be coupled with the use of beef semen, and the expected result would be a further improvement in beef production from the dairy herd because of the lower replacement rate of dairy crossbred cows. A breeding scheme in which the rearing of Holstein purebreds to produce 2- and 3-way dairy crossbreed cows, all through sexed semen, is combined with terminal crossing of the dairy crossbreds with beef bulls using conventional semen has also been proposed (Kargo et al., 2014).

\section{CONCLUSIONS}

On the basis of a model that takes into account for the cows the effect of the category, breed, milk yield, lactation stage, order of insemination, and season, the combined use of sexed semen to produce purebred replacement dairy heifers and conventional beef semen to produce terminal beef $\times$ dairy crossbred calves does not reduce herd fertility. This is because the possible, nonsignificant reduction in the conception rate associated with the use of sexed semen is compensated for by the significant increase in the conception rate associated with the use of beef semen. Taking into consideration the number of sexed semen doses needed per pregnancy and the welfare of the cows with regard to possible cases of dystocia, sexed dairy semen is particularly recommended for use in virgin heifers and beef semen is recommended for use in mature cows. A combination of sexed dairy semen and conventional beef semen could also be used in rotational dairy crossbreeding systems; this would exploit the significant increase in conception rate due to heterosis also in the production of replace- 
ment heifers and a further increase in beef production because of the lower replacement rate of crossbred dairy cows. The quantitative and qualitative increase in beef production from dairy herds has the potential to reduce the ecological footprint of beef production and improve the profitability of dairy farms. The financial benefit will depend, in particular, on the (decreasing) cost of sexed semen and on the disparity in the price of purebred dairy bull calves and beef $\times$ dairy bull and heifer calves. In the case of markets favoring lean, muscular veal and beef carcasses, such as in Italy, the combined use of sexed purebred semen and conventional beef semen is particularly advantageous when double-muscled sires are used.

\section{ACKNOWLEDGMENTS}

The authors thank the Veneto regional government for funding the meetBULL project. Moreover, they thank the Associazione Regionale Allevatori del Veneto (ARAV, Veneto Regional Breeders Association, Vicenza, Italy) and VBA SCA Veneto (Vicenza, Italy) for maintaining the contacts with and collecting data from the dairy farmers involved in the project. Many thanks to Adriano Toffoli, director of ARAV, and to the technicians of ARAV and Department of Agronomy, Food, Natural Resources, Animals and Environment (Padova, Italy) involved in the project for their collaboration. The authors declare that there is no conflict of interest.

\section{REFERENCES}

Albera, A., R. Mantovani, G. Bittante, A. F. Groen, and P. Carnier. 2001. Genetic parameters for daily live-weight gain, live fleshiness and bone thinness in station-tested Piemontese young bulls. Anim. Sci. 72:449-456. https://doi.org/10.1017/S1357729800051961.

Barrientos-Blanco, J. A., N. M. Thompson, N. J. O. Widmar, C. A. Wolf, and L. Unruh Snyder. 2018. Expected value of crossbred dairy cattle artificial insemination breeding strategies in virgin heifers and lactating cows. Livest. Sci. 211:66-74. https://doi.org/ 10.1016/j.livsci.2018.03.005.

Beck, H. E., N. E. Zimmermann, T. R. McVicar, N. Vergopolan, A. Berg, and E. F. Wood. 2018. Present and future Köppen-Geiger climate classification maps at 1-km resolution. Sci. Data 5:180214. https://doi.org/10.1038/sdata.2018.214.

Bello, N. M., J. S. Stevenson, and R. J. Tempelman. 2012. Invited review: Milk production and reproductive performance: Modern interdisciplinary insights into an enduring axiom. J. Dairy Sci. 95:5461-5475. https://doi.org/10.3168/jds.2012-5564.

Berton, M., J. Agabriel, L. Gallo, M. Lherm, M. Ramanzin, and E. Sturaro. 2017. Environmental footprint of the integrated FranceItaly beef production system assessed through a multi-indicator approach. Agric. Syst. 155:33-42. https://doi.org/10.1016/j.agsy 2017.04.005.

Berton, M., G. Cesaro, L. Gallo, M. Ramanzin, and E. Sturaro. 2018. Sources of variation of the environmental impact of cereal-based intensive beef finishing herds. Ital. J. Anim. Sci. 17:767-776. https: //doi.org/10.1080/1828051X.2018.1423581.

Bittante, G., A. Cecchinato, F. Tagliapietra, R. Verdiglione, A. Simonetto, and S. Schiavon. 2018. Crossbred young bulls and heifers sired by double-muscled Piemontese or Belgian Blue bulls exhibit different effects of sexual dimorphism on fattening performance and muscularity but not on meat quality traits. Meat Sci. 137:2433. https://doi.org/10.1016/j.meatsci.2017.11.004.

Bittante, G., R. Negrini, M. Bergamaschi, A. Cecchinato, and H. O. Toledo-Alvarado. 2020. Short communication: Pure-breeding with sexed semen and crossbreeding with semen of double-muscled sires to improve beef production from dairy herds: Weight and value of calves obtained. J. Dairy Sci. 103:5258-5262. https://doi.org/10 .3168/jds.2019-18011.

Buckley, F., N. Lopez-Villalobos, and B. J. Heins. 2014. Crossbreeding: Implications for dairy cow fertility and survival. Animal 8(Suppl. 1):122-133.

Butler, S. T., I. A. Hutchinson, A. R. Cromie, and L. Shalloo. 2014. Applications and cost benefits of sexed semen in pasture-based dairy production systems. Animal 8(Suppl. 1):165-171.

Butler, W. R. 2003. Energy balance relationships with follicular development, ovulation and fertility in postpartum dairy cows. Livest. Prod. Sci. 83:211-218. https://doi.org/10.1016/S0301 -6226(03)00112-X.

Castillo-Juarez, H., P. A. Oltenacu, R. W. Blake, C. E. Mcculloch, and E. G. Cienfuegos-Rivas. 2000. Effect of herd environment on the genetic and phenotypic relationships among milk yield, conception rate, and somatic cell score in Holstein cattle. J. Dairy Sci. 83:807-814. https://doi.org/10.3168/jds.S0022-0302(00)74943-5.

Cerchiaro, I., M. Cassandro, R. Dal Zotto, P. Carnier, and L. Gallo. 2007. A field study on fertility and purity of sex-sorted cattle sperm. J. Dairy Sci. 90:2538-2542. https://doi.org/10.3168/jds 2006-694.

Clasen, J. B., E. Norberg, P. Madsen, J. Pedersen, and M. Kargo. 2017. Estimation of genetic parameters and heterosis for longevity in crossbred Danish dairy cattle. J. Dairy Sci. 100:6337-6342. https://doi.org/10.3168/jds.2017-12627.

Coopman, F., A. Krafft, J. Dewulf, A. Van Zeveren, and N. Gengler. 2007. Estimation of phenotypic and genetic parameters for weight gain and weight at fixed ages in the double-muscled Belgian Blue beef breed using field records. J. Anim. Breed. Genet. 124:20-25. https://doi.org/10.1111/j.1439-0388.2007.00632.x.

Cottle, D. J., M. Wallace, P. Lonergan, and A. G. Fahey. 2018. Bioeconomics of sexed semen utilization in a high-producing HolsteinFriesian dairy herd. J. Dairy Sci. 101:4498-4512. https://doi.org/ 10.3168/jds.2017-13172.

Dal Zotto, R., M. Penasa, M. De Marchi, M. Cassandro, N. López-Villalobos, and G. Bittante. 2009. Use of crossbreeding with beef bulls in dairy herds: Effect on age, body weight, price, and market value of calves sold at livestock auctions. J. Anim. Sci. 87:3053-3059. https://doi.org/10.2527/jas.2008-1620.

Dash, S., A. K. Chakravarty, A. Singh, A. Upadhyay, M. Singh, and S. Yousuf. 2016. Effect of heat stress on reproductive performances of dairy cattle and buffaloes: A review. Vet. World 9:235-244. https: //doi.org/10.14202/vetworld.2016.235-244.

De Rensis, F., F. Lopez-Gatius, I. García-Ispierto, G. Morini, and R. J. Scaramuzzi. 2017. Causes of declining fertility in dairy cows during the warm season. Theriogenology 91:145-153. https://doi.org/ 10.1016/j.theriogenology.2016.12.024.

Dezetter, C., N. Bareille, D. Billon, C. Côrtes, C. Lechartier, and H. Seegers. 2017. Changes in animal performance and profitability of Holstein dairy operations after introduction of crossbreeding with Montbéliarde, Normande, and Scandinavian Red. J. Dairy Sci. 100:8239-8264. https://doi.org/10.3168/jds.2016-11436.

Djedović, R., V. Bogdanović, D. Stanojević, Z. Nemes, A. Gáspárdy, and S. Cseh. 2016. Involuntary reduction in vigour of calves born from sexed semen. Acta Vet. Hung. 64:229-238. https://doi.org/ 10.1556/004.2016.023.

Ettema, J. F., J. R. Thomasen, L. Hjortø, M. Kargo, S. Østergaard, and A. C. Sørensen. 2017. Economic opportunities for using sexed semen and semen of beef bulls in dairy herds. J. Dairy Sci. 100:4161-4171. https://doi.org/10.3168/jds.2016-11333.

European Commission. 2011. EU beef farms report 2010 based on FADN data. Accessed Mar. 2020. https://ec.europa.eu/ agriculture/rica/pdf/sa502_beefreport.pdf. 
Hagiya, K., K. Hayasaka, T. Yamazaki, T. Shirai, T. Osawa, Y. Terawaki, Y. Nagamine, Y. Masuda, and M. Suzuki. 2017. Effects of heat stress on production, somatic cell score and conception rate in Holsteins. Anim. Sci. J. 88:3-10. https://doi.org/10.1111/asj .12617 .

Hayakawa, H. 2012. Mini review. Sperm sexing in the cattle industry. J. Mamm. Ova Res. 29:119-123. https://doi.org/10.1274/jmor.29 .119 .

Hazel, A. R., B. J. Heins, and L. B. Hansen. 2017. Fertility, survival, and conformation of Montbéliarde $\times$ Holstein and Viking Red $\times$ Holstein crossbred cows compared with pure Holstein cows during first lactation in 8 commercial dairy herds. J. Dairy Sci. 100:94479458. https://doi.org/10.3168/jds.2017-12824.

Healy, A. A., J. K. House, and P. C. Thomson. 2013. Artificial insemination field data on the use of sexed and conventional semen in nulliparous Holstein heifers. J. Dairy Sci. 96:1905-1914. https:// doi.org/10.3168/jds.2012-5465.

Heins, B. J., L. B. Hansen, and A. De Vries. 2012. Survival, lifetime production, and profitability of Normande $\times$ Holstein, Montbéliarde $\times$ Holstein, and Scandinavian Red $\times$ Holstein crossbreds versus pure Holsteins. J. Dairy Sci. 95:1011-1021. https://doi.org/ 10.3168/jds.2011-4525.

Heuer, C., D. Kendall, C. Sun, J. Deeb, J. Moreno, and R. Vishwanath. 2017. Evaluation of conception rates of sex-sorted semen in commercial dairy farms over the last five years. J. Dairy Sci. 100(E-Suppl.):198. (Abstr.)

Hohenboken, W. D. 1999. Applications of sexed semen in cattle production. Theriogenology 52:1421-1433. https://doi.org/10.1016/ S0093-691X(99)00227-7.

Holden, S. A., and S. T. Butler. 2018. Review: Applications and benefits of sexed semen in dairy and beef herds. Animal 12(Suppl. 1):97-103.

Hutchinson, I. A., L. Shalloo, and S. T. Butler. 2013. Expanding the dairy herd in pasture-based systems: The role of sexed semen use in virgin heifers and lactating cows. J. Dairy Sci. 96:6742-6752. https://doi.org/10.3168/jds.2012-6476.

ISMEA. 2019. Carne bovina - Prezzi medi all'origine. Accessed May 20, 2019. http://www.ismeamercati.it/analisi-e-studio-filiere -agroalimentari.

Kargo, M., J. Ettema, M. Fjordside, L. H. Sørensen, and L. Hjortø. 2014. Combi-Cross - the use of new technologies for improving dairy crossbreeding programs. Page 844 in Proc. 10th World Congress of Genetics Applied to Livestock Production, Vancouver, BC, Canada. American Society of Animal Science, Champaign, IL.

Kim, I. H., and J. K. Jeong. 2019. Risk factors limiting first service conception rate in dairy cows and their economic impact. AsianAustralas. J. Anim. Sci. 32:519-526.

Kizilkaya, K., P. Carnier, A. Albera, G. Bittante, and R. J. Tempelman. 2003. Cumulative t-link threshold models for the genetic analysis of calving ease scores. Genet. Sel. Evol. 35:489-512. https: //doi.org/10.1186/1297-9686-35-6-489.

Kolkman, I., S. De Vliegher, G. Hoflack, M. Van Aert, J. Laureyns, D. Lips, A. de Kruif, and G. Opsomer. 2007. Protocol of the caesarean section as performed in daily bovine practice in Belgium. Reprod. Domest. Anim. 42:583-589. https://doi.org/10.1111/j.1439 -0531.2006.00825.x.

Kurykin, J., T. Hallap, M. Jalakas, P. Padrik, T. Kaart, A. Johannisson, and Ü. Jaakma. 2016. Effect of insemination-related factors on pregnancy rate using sexed semen in Holstein heifers. Czech J. Anim. Sci. 61:568-577. https://doi.org/10.17221/12/2016-CJAS.

LeBlanc, S. 2010. Assessing the association of the level of milk production with reproductive performance in dairy cattle. J. Reprod. Dev. 56(Suppl.):S1-S7. https://doi.org/10.1262/jrd.1056S01.

Lenz, R. W., C. Gonzalez-Marin, T. B. Gilligan, J. M. DeJarnette, M. D. Utt, L. A. Helser, E. Hasenpusch, K. M. Evans, J. F. Moreno, and R. Vishwanath. 2017. SexedULTRA, a new method of processing sex-sorted bovine sperm improves conception rates. Reprod. Fertil. Dev. 29:203-204. https://doi.org/10.1071/RDv29n1Ab190.

López-Gatius, F. 2012. Factors of a noninfectious nature affecting fertility after artificial insemination in lactating dairy cows. A review. Theriogenology 77:1029-1041. https://doi.org/10.1016/j theriogenology.2011.10.014.

Lucy, M. C. 2001. Reproductive loss in high-producing dairy cattle: Where will it end? J. Dairy Sci. 84:1277-1293. https://doi.org/10 .3168/jds.S0022-0302(01)70158-0.

Lucy, M. C. 2003. Mechanisms linking nutrition and reproduction in postpartum cows. Reprod. Suppl. 61:415-427.

Lucy, M. C. 2019. Symposium review: Selection for fertility in the modern dairy cow - Current status and future direction for genetic selection. J. Dairy Sci. 102:3706-3721. https://doi.org/10.3168/jds 2018-15544.

Malchiodi, F., A. Cecchinato, and G. Bittante. 2014a. Fertility traits of purebred Holsteins and 2- and 3-breed crossbred heifers and cows obtained from Swedish Red, Montbéliarde, and Brown Swiss sires. J. Dairy Sci. 97:7916-7926. https://doi.org/10.3168/jds.2014 $-8156$.

Malchiodi, F., A. Cecchinato, M. Penasa, C. Cipolat-Gotet, and G. Bittante. 2014b. Milk quality, coagulation properties, and curd firmness modeling of purebred Holsteins and first- and secondgeneration crossbred cows from Swedish Red, Montbéliarde, and Brown Swiss bulls. J. Dairy Sci. 97:4530-4541. https://doi.org/10 $.3168 /$ jds.2013-7868.

McCullock, K., D. L. K. Hoag, J. Parsons, M. Lacy, G. E. Seidel Jr., and W. Wailes. 2013. Factors affecting economics of using sexed semen in dairy cattle. J. Dairy Sci. 96:6366-6377. https://doi.org/ 10.3168/jds.2013-6672.

Mc Hugh, N., A. G. Fahey, R. D. Evans, and D. P. Berry. 2010. Factors associated with selling price of cattle at livestock marts. Animal 4:1378-1389. https://doi.org/10.1017/S1751731110000297.

Morton, J. M. 2006. Potential for bias in observed associations between milk yield and reproductive performance in dairy cows. In Proc. 11th Int. Symp. Vet. Epidemiol. Econ. Accessed Jul. 10, 2012. http://www.sciquest.org.nz/node/63741.

Pryce, J. E., M. D. Royal, P. C. Garnsworthy, and I. L. Mao. 2004. Fertility in the high-producing dairy cow. Livest. Prod. Sci. 86:125-135. https://doi.org/10.1016/S0301-6226(03)00145-3.

R Core Team. 2016. R: A Language and Environment for Statistical Computing. R Found. Stat. Comput. 1:409. https://doi.org/10 .1007/978-3-540-74686-7.

Rodney, R. M., P. Celi, W. Scott, K. Breinhild, J. E. P. Santos, and I. J. Lean. 2018. Effects of nutrition on the fertility of lactating dairy cattle. J. Dairy Sci. 101:5115-5133. https://doi.org/10.3168/ jds.2017-14064

Saha, S., L. Carraro, G. Bittante, and L. Gallo. 2018. Body and milk quality traits of purebred Holstein and three-generation crossbred cows from Viking Red, Montbéliarde, and Holstein sires. J. Cent. Eur. Agric. 19:760-765. https://doi.org/10.5513/JCEA01/19.4 .2334 .

Saha, S., F. Malchiodi, C. Cipolat-Gotet, G. Bittante, and L. Gallo. 2017. Effect of crossbreeding of Holsteins cows with Montbéliarde and Swedish Red in first and second generation on cheese yield traits. Agric. Conceptus Scient. 82:241-244.

Scanavez, A. L. A., A. G. Arruda, J. S. Stevenson, and L. G. D. Mendonça. 2019. Evaluation of seasonal patterns and herd level traits associated with insemination risk in large dairy herds in Kansas. PLoS One 14:e0217080. https://doi.org/10.1371/journal .pone.0217080.

Seidel, G. E. Jr. 2014. Update on sexed semen technology in cattle. Animal 8(Suppl. 1):160-164. https://doi.org/10.1017/ S1751731114000202.

Shonka-Martin, B. N., A. R. Hazel, B. J. Heins, and L. B. Hansen. 2019. Three-breed rotational crossbreds of Montbéliarde, Viking Red, and Holstein compared with Holstein cows for dry matter intake, body traits, and production. J. Dairy Sci. 102:871-882. https://doi.org/10.3168/jds.2018-15318.

Stocco, G., C. Cipolat-Gotet, A. Ferragina, P. Berzaghi, and G. Bittante. 2019. Accuracy and biases in predicting the chemical and physical traits of many types of cheeses using different visible and near-infrared spectroscopic techniques and spectrum intervals. J. Dairy Sci. 102:9622-9638. https://doi.org/10.3168/jds.2019-16770. 
Tiezzi, F., C. Maltecca, A. Cecchinato, M. Penasa, and G. Bittante. 2012. Genetic parameters for fertility of dairy heifers and cows at different parities and relationships with production traits in first lactation. J. Dairy Sci. 95:7355-7362. https://doi.org/10.3168/jds $.2012-5775$

Tiezzi, F., C. Maltecca, A. Cecchinato, M. Penasa, and G. Bittante. 2013. Thin and fat cows, and the nonlinear genetic relationship between body condition score and fertility. J. Dairy Sci. 96:6730 6741. https://doi.org/10.3168/jds.2013-6863.

Tiezzi, F., C. Maltecca, M. Penasa, A. Cecchinato, Y. M. Chang, and G. Bittante. 2011. Genetic analysis of fertility in the Italian Brown Swiss population using different models and trait definitions. J. Dairy Sci. 94:6162-6172. https://doi.org/10.3168/jds.2011-4661.

Toledo-Alvarado, H., A. Cecchinato, and G. Bittante. 2017. Fertility traits of Holstein, Brown Swiss, Simmental, and Alpine Grey cows are differently affected by herd productivity and milk yield of individual cows. J. Dairy Sci. 100:8220-8231. https://doi.org/10 3168/jds.2016-12442.

Tubman, L. M., Z. Brink, T. K. Suh, and G. E. Seidel Jr.. 2004. Characteristics of calves produced with sperm sexed by flow cytometry/ cell sorting. J. Anim. Sci. 82:1029-1036. https://doi.org/10.2527/ 2004.8241029x.
VanRaden, P. M. 2004. Invited review: Selection on net merit to improve lifetime profit. J. Dairy Sci. 87:3125-3131. https://doi.org/ 10.3168/jds.S0022-0302(04)73447-5.

Vishwanath, R., and J. F. Moreno. 2018. Review: Semen sexing - Current state of the art with emphasis on bovine species. Animal 12(Suppl. 1):s85-s96. https://doi.org/10.1017/ S1751731118000496.

Walsh, S. W., E. J. Williams, and A. C. O. Evans. 2011. A review of the causes of poor fertility in high milk producing dairy cows. Anim. Reprod. Sci. 123:127-138. https://doi.org/10.1016/j .anireprosci.2010.12.001

\section{ORCIDS}

Giovanni Bittante ํㅜ https://orcid.org/0000-0001-7137-7049

Matteo Bergamaschi 이 https://orcid.org/0000-0002-3983-5019

Alessio Cecchinato 10 https://orcid.org/0000-0003-3518-720X

Hugo Toledo-Alvarado 으 https://orcid.org/0000-0001-7854-1219 